\title{
Influence of graphene-based materials on invertebrate and vertebrate
}

\author{
Zhihui Huang ${ }^{1}$, Ning Gao ${ }^{1}$, Jianing Xing ${ }^{1}$, Siyi Zhang ${ }^{1}$ and Jing Hou ${ }^{\text {a }}$ \\ ${ }^{1}$ MOE Key Laboratory of Resources and Environmental Systems Optimization, College of Environmental Science and \\ Engineering, North China Electric Power University, Beijing, 102206, PR China
}

\begin{abstract}
With the rapid increased application of graphene and related materials (GRMs) in the industrial community, its release in the environment is gradually increased. The toxic effects of GRMs has drawn our attention. We characterised the toxic effects of GRMs on invertebrates and vertebrates and the common toxic mechanism, which can be classified as physical and chemical damage. This work gives a brief understanding of the toxic effects and mechanisms of GRMs.
\end{abstract}

\section{Introduction}

The application of Graphene and related materials (GRMs) including graphene, reduced graphene, graphene oxide and some other related hybrids have been increased rapidly in recent decades. In medicine, GRMs have been proposed for many potential applications like antibacterial agents, drug carriers, and cancer treatment, etc. ${ }^{[1-3]}$. Thus, the chances of direct contact with human body are greatly increased. At the same time, the negative effects of GRMs have been constantly reported. Therefore, we summarized the characteristics and general patterns of toxic effects of GRMs on invertebrates and vertebrates. Meanwhile, we also gave a classifiable exposition of its toxicity mechanisms. This work contributes to the environmental risk assessment of GRMs.

\section{Toxic effects of GRMs on invertebrates}

D. magna is commonly used invertebrate model species for evaluating the aquatic toxicity. Some of the toxic effects of GRMs on invertebrates and vertebrates are shown in table 1. Oxidative stress, growth inhibition, reproductive toxicity, neurotoxicity, the regenerative capacity damage and some other physiological impacts were the common negative effects of GRMs on invertebrates ${ }^{[4-7]}$. Generally speaking, the effects on invertebrates are time-dependent. For example, the ROS levels of D. magna increase apparently with exposure time as reported by $\mathrm{Lv}$ et al. When exposed to $5 \mathrm{mg} / \mathrm{L}$ and $20 \mathrm{mg} / \mathrm{L} \mathrm{GO}$, the fluorescence intensity of D. magna at $24 \mathrm{~h}$ was significantly lower than that at $48 \mathrm{~h}^{[8]}$. The

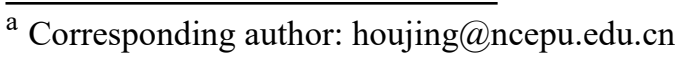

concentration of GRMs in the actual environmental is usually lower than its acute lethal concentration of GRMs on organisms, so toxicities caused by low concentration cannot be ignored. The reproductive toxicity of GO on C. elegans reported by Chatterjee et al. addressed that $\mathrm{GO}$ exposure at $5 \mathrm{mg} / \mathrm{L}$ activated $P O P-1$ and then suppressed the expression of ELG-5 (gene) through wingless type-MAPK crosstalk pathway, consequently leading to reproductive failure ${ }^{[4]}$. The reproduction of organisms is an important factor for the stability of ecosystems, so the reproductive toxicity of GRMs should not be neglect. In addition, there is a study on invertebrates found that GRMs with lower $\mathrm{C} / \mathrm{O}$ atoms ration are more toxic, which may be due to the decrease of O-functional groups leading to the decreased activity ${ }^{[9]}$. This is of reference significance for the selection of GRMs with low toxicity.

\section{Toxic effects of GRMs on vertebrates}

D. rerio is a fluently used model organism in toxicological studies. The impact of GRMs on vertebrate can better reflect the potential impact on human to some extent than other organisms because vertebrates are higher grade animals ${ }^{[10,11]}$. The increase of ROS levels, cell apoptotic, necrotic, pericardial edema, malformation and tissue damage were all negative effects of GRMs that have been reported on zebrafish or its larva $a^{[12-14]}$. Besides, zebrafish larvae exposed to ultra-trace GO (0.01 $\mathrm{mg} / \mathrm{L}$ ) induced a loss of more than $90 \%$ of dopamine neurons, a $69 \%$ to $522 \%$ increase in lewy bodies and other parkinson's disease-like symptoms ${ }^{[15]}$. These are all symptoms that may occur in human beings. Meanwhile, there was report said brain might be one of the primary targets of graphene ${ }^{[16]}$. There were also concentration- 
dependent effects of GRMs was reported. Immunoreactivity studies found that interleukin-1 and interleukin-6 (proinflammatory cytokines) increased with GO concentration after exposure of zebrafish to 1, 5, 10 and $50 \mathrm{mg} / \mathrm{L}$ GO for 14 days $^{[17]}$. These two kind of cytok-

Table 1. Toxic effects of GRMs on different invertebrates and vertebrates.

\begin{tabular}{|c|c|c|c|c|}
\hline GRMs & Species & Exposure condition & Efftcts & Refe-rence \\
\hline GO & D. magna & $\begin{array}{l}\text { Exposed to } 0,0.01,0.1,1.0,10,50 \mathrm{mg} / \mathrm{L} \text {. The } \\
\text { mediums were renewed every } 48 \mathrm{~h}\end{array}$ & $\begin{array}{c}21 \mathrm{~d} \mathrm{LC} \mathrm{C}_{50}: 3.3 \mathrm{mg} / \mathrm{L} \\
\text { ROS: } 136 \% \text { of the control; } \\
\text { SOD and CAT activities were increased }\end{array}$ & [18] \\
\hline GO-HA & D. magna & Three concentrations of HA $(5,10,25 \mathrm{mg} / \mathrm{L})$ & $\begin{array}{l}21 \mathrm{~d} \mathrm{LC}_{50}: 9.7 \mathrm{mg} / \mathrm{L} ; \\
\text { Reduced the time to produce the first brood; } \\
\text { Production of neonates increased; } \\
\text { SOD and CAT activities were decreased with } \\
\text { increasing concentrations of HA. }\end{array}$ & {$[18]$} \\
\hline GO & A. salina & $\begin{array}{c}10 \text { instar nauplii (6-24 h old) were placed per well } \\
\text { containing } 2 \mathrm{~mL} \text { ( } 24 \text {-well plates) of GO solutions at } \\
24^{\circ} \mathrm{C}\end{array}$ & $\mathrm{LC}_{50}: 489.30 \pm 19.41 \mathrm{mg} / \mathrm{L}$ & [19] \\
\hline GO & D. magna & $\begin{array}{l}\text { Exposed to } 0,0.1,1.0,10 \text { and } 100 \mathrm{mg} / \mathrm{L} \mathrm{GO} \text { at } 20 \pm \\
2^{\circ} \mathrm{C}\end{array}$ & $\mathrm{EC}_{50}: 0.58(0.35-2.07) \mathrm{mg} / \mathrm{L}$ & [20] \\
\hline GO & A. salina & $\begin{array}{c}\text { Exposed to } \mathrm{GO} \text { at } 20 \pm 2^{\circ} \mathrm{C} \text { for } 96 \mathrm{~h} \text { with daily renewal } \\
\text { of the test solutions. }\end{array}$ & $\mathrm{EC}_{50}:>100 \mathrm{mg} / \mathrm{L}$ & [20] \\
\hline GO & C. sancticaroli. & $\begin{array}{l}\text { Exposed to test solution at } 23 \text { to } 26^{\circ} \mathrm{C} \text { in a } 16 / 8 \\
\text { light/dark cycle and mild aeration }\end{array}$ & EC50: $>100 \mathrm{mg} / \mathrm{L}$ & [20] \\
\hline GO & D. magna & $\begin{array}{l}10 \text { individuals exposed to } 0,1,5,10,20 \text {, and } 50 \mathrm{mg} / \mathrm{L} \\
\mathrm{GO} \text { at } 25 \pm 2^{\circ} \mathrm{C} \text { with natural light/dark cycle }\end{array}$ & $\begin{array}{l}\text { Immobility and mortality displayed dose- and time- } \\
\text { dependent; } \\
\text { 72-h LC } \mathrm{LC}_{50}: 45.4 \mathrm{mg} / \mathrm{L} \text {; } \\
\text { GO filled most of the gut after } 12 \mathrm{~h} \text { of exposure }\end{array}$ & [8] \\
\hline GO & A. salina & $\begin{array}{c}\text { The cysts exposed to } \mathrm{GO} \text { at } 28{ }^{\circ} \mathrm{C} \text { using } 24 \text {-well plates } \\
\text { with shaking }\end{array}$ & $\begin{array}{l}\text { Dose-dependent decreases in hatching rates and } \\
\text { swimming speed; } \\
\text { Dose-dependent increases in mortality rates; } \\
\text { MDA content, ROS and T-AOC increased }\end{array}$ & [21] \\
\hline GO & C. dubia & $\begin{array}{l}\text { Chronic assay: exposed to sub-lethal concentrations of } \\
0,0.05,0.1,0.2,0.4 \text { and } 0.8 \mathrm{mg} / \mathrm{L} \mathrm{GO} \text { with renewal of } \\
\text { exposure medium every } 48 \mathrm{~h}\end{array}$ & $\begin{array}{c}48 \mathrm{~h}-\mathrm{EC}_{50}: 1.25 \mathrm{mg} / \mathrm{L} ; \\
\text { ROS increased in all concentrations; } \\
\text { Significantly decreased in the filtration and ingestion } \\
\text { rates; } \\
\text { GO was accumulated mainly on C. dubia digestive } \\
\text { tract. }\end{array}$ & [22] \\
\hline GO & D. rerio embryos & $\begin{array}{c}\text { Exposed to GO }(1,10 \text { and } 100 \mu \mathrm{g} / \mathrm{L}) \text { from } 2.5 \mathrm{hpf} \text { to } 7 \\
\operatorname{dpf}\end{array}$ & $\begin{array}{c}\text { Increased malformation rates; } \\
\text { Changed the levels of proteins associated with the } \\
\text { cytoskeleton/muscle system and mitochondrial } \\
\text { respiratory chain; } 100 \mu \mathrm{g} / \mathrm{L} \mathrm{GO} \text { decreased the GSH } \\
\text { content }\end{array}$ & [23] \\
\hline GO & D. rerio embryos & Exposed to $0,5,25,50 \mathrm{mg} / \mathrm{mL} \mathrm{GO}$ at $28 \pm 5^{\circ} \mathrm{C}$ & $\begin{array}{l}\text { Hatching rates slightly decreased at } 5 \mathrm{mg} / \mathrm{mL} \text {, and } \\
\text { slightly increased at higher concentration }(25,50 \\
\qquad \mathrm{mg} / \mathrm{mL})\end{array}$ & [24] \\
\hline GO & D. rerio embryos & Exposed to $0,1,10$, and $100 \mathrm{mg} / \mathrm{L} \mathrm{GO}$ for $96 \mathrm{~h}$ & $\begin{array}{c}\text { Larvae exposed to } 100 \mathrm{mg} / \mathrm{L} \mathrm{GO} \text { were significantly } \\
\text { shorter; } \\
\text { The exposure to GO did not change the CAT or GST } \\
\text { activity }\end{array}$ & [25] \\
\hline bw-GO & D. rerio embryos & Exposed to $100 \mathrm{mg} / \mathrm{L} \mathrm{bw}-\mathrm{GO}$ for $96 \mathrm{~h}$ & $\begin{array}{c}\text { Exposed to } 100 \mathrm{mg} / \mathrm{L} \text { bw-GO were approximately } 3 \% \\
\text { bigger than those exposed to } 100 \mathrm{mg} / \mathrm{L} \mathrm{GO} \\
\text { A } 32 \% \text { decrease in the GST activity }\end{array}$ & [25] \\
\hline GO & D. rerio & $\begin{array}{l}\text { Exposed to GO for } 24 \text { or } 72 \mathrm{~h} \text { in the short-term assays } \\
\text { and for } 14 \text { days in the chronic assay }\end{array}$ & $\begin{array}{l}\text { Did not reveal DNA damage; } \\
\text { Induced significant ROS production; } \\
\text { Caused some histological disturbances }\end{array}$ & [12] \\
\hline
\end{tabular}

Caption: Graphene oxide (GO); GO-humic acid (GO-HA); Base washed GO (bw-GO)

ines also play a role of immune regulation in human body, so zebrafish is a good choice for the speculation of the effects of GRMs on human being because of its high homology with human genes.

\section{Toxic mechanisms of GRMs}

The toxic mechanism of GRMs can be classified as physical and chemical influences. Common physical damage involves mechanical cutting of membrane, extraction of phospholipids, adsorption of extracellular nutrients and shadowing effect on photosynthetic $\operatorname{organisms}^{[26-29]}$. The chemical mechanisms are mainly chemical interaction between materials and organism subsequently causing oxidative stress, metabolic disorders, DNA damage, inflammatory reactions, apoptosis, and necrosis, etc. ${ }^{[12,19,30]}$. Generally, GRMs adsorb on living organisms due to electrostatic attraction, other intermolecular forces or random contact. They enter cells through physical interaction and cause various physiological reactions due to chemical influences. 
Most GRMs have sharp or rough edges, which allow them penetrate cell membrane or cell wall easily, resulting in cellular contents flow out or organelle destruction $^{[31,32]}$. Both experimental and characterization results confirmed that GO with vertically aligned has stronger antibacterial properties than the random array, which indirectly illustrates that physical film damage is one of the toxicity mechanisms ${ }^{[33]}$. Another important physical mechanism is phospholipid extraction, which had been testified though both experiment and computer simulation. Phospholipid extraction is the result of the realignment of phospholipid molecules on the nanosheets caused by the special two-dimensional structure of graphene nanosheets and the hydrophobicity of phospholipid molecules ${ }^{[27]}$. The other two common physical damage mechanisms are the shadowing effect on photosynthetic organisms and the adsorption of extracellular nutrients result from intermolecular forces. Many studies have shown that GRMs could cause a shadowing effect on algae and further reduce its photosynthesis and chlorophyll level resulting the death of cells ${ }^{[29,32,34]}$. Lack of essential elements will have adverse effect on cell growth. Research of yu et al. showed that GO could adsorb extracellular iron of unicellular organisms and destroy metabolism where iron is necessary causing the cell growth and metabolism inhibition due to iron deficiency ${ }^{[28]}$.

GRMs as foreign substances can react with cellular biomolecules, trigger the immune response and cause oxidative stress. To be specific, graphene, rGO, hydrogenated graphene and many other GRMs have been confirmed to replace the role of metal ions such as $\mathrm{Fe}^{2+}$ to catalyze a Fenton-like reactions, schematic of which can be seen in figure $1 \mathrm{~A}$ and $1 \mathrm{~B}^{[35-37]}$. GRMs act as Fenton-actives to catalyze the $\mathrm{H}_{2} \mathrm{O}_{2}$ to form $\cdot \mathrm{OH}$ or other radials, which increase the ROS level. Early study has shown that several graphene-based nanomaterials cause glutathione deactivation under extracellular aerobic conditions $^{[38]}$. Glutathione is a vital intracellular antioxidant, and if it is inactivated, the ROS level will increase significantly. In addition, $\mathrm{Li}$ et al. found that GRMs can extract respiratory chain electrons, causing ATP generation to be blocked and thus dying from energy depletion ${ }^{[39]}$. Whereas, these are merely the biomolecules we have found that interact with GRMs. Because of the redox activity and a variety of functional groups of GRMs and adsorption effect resulted from electrostatic or intermolecular forces, it may also affect the function of other substances in the cells. In short, the chemical interaction between GRMs and biomolecules was the main chemical mechanism.

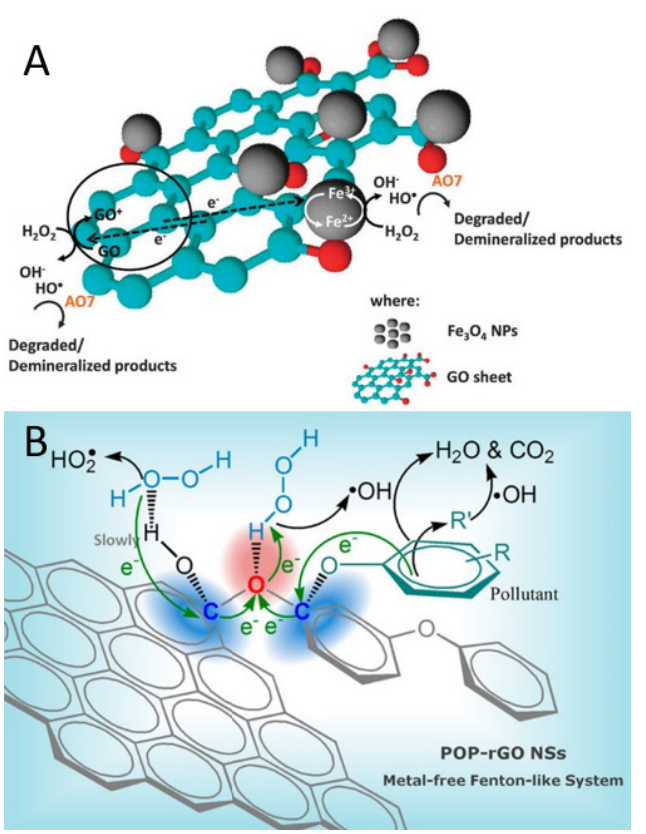

Figure 1. Schematic of (A) $\mathrm{GO}_{-} \mathrm{Fe}_{3} \mathrm{O}_{4}$ and 4-phenoxyphenolfunctionalized (B) rGO catalyzed the metal-free Fenton-like reaction. Reuse with permission from reference ${ }^{[40]}$ and $d^{[41]}$.

\section{Conclusions}

Oxidative stress, growth inhibition, membrane damage, cell apoptotic, necrotic and tissue damage were the most fluently reported toxic effects of GRMs. The harmful effects of graphene-based products should be assessed before they are widely used. At present, researches about the effects of GRMs at low-concentration and long-time exposure is not adequate. The main toxic mechanisms of GRMs are the physical and chemical interaction between materials and organisms. There are usually both physical damage and chemical damage in every negative effect. This work is of reference for the research of the GRMs toxicology.

\section{References}

1. M. Yousefi, M. Dadashpour, M. Hejazi, M. Hasanzadeh, B. Behnam, M. De La Guardia, N. Shadjou, A. Mokhtarzadeh, Materials Science \& Engineering C-Materials for Biological Applications 74, 568 (2017)

2. X. Yang, X. Zhang, Y. Ma, Y. Huang, Y. Wang, Y. Chen, J Mater Chem 19, 2710 (2009)

3. Z. Liu, J.T. Robinson, X. Sun, H. Dai, JACS 130, 10876 (2008)

4. N. Chatterjee, Y. Kim, J. Yang, C.P. Roca, S.W. Joo, J. Choi, Nanotoxicology 11, 76 (2017)

5. M. Qu, Y. Li, Q. Wu, Y. Xia, D. Wang, Nanotoxicology 11, 520 (2017)

6. L. De Marchi, V. Neto, C. Pretti, E. Figueira, L. Brambilla, M.J. Rodriguez-Douton, F. Rossella, M. Tommasini, C. Furtado, A.M.V.M. Soares, et al., 
Comparative Biochemistry and Physiology CToxicology \& Pharmacology 193, 50 (2017)

7. A.L. Fernandes, M.E. Josende, J.P. Nascimento, A.P. Santos, S.K. Sahoo, F.M. Rodrigues Da Silva, Jr., L.A. Romano, C.A. Furtado, W. Wasielesky, J.M. Monserrat, et al., Toxicology Research 6, 205 (2017)

8. X. Lv, Y. Yang, Y. Tao, Y. Jiang, B. Chen, X. Zhu, Z. Cai, B. Li, Environ Pollut 234, 953 (2018)

9. Y. Liu, W. Han, Z. Xu, W. Fan, W. Peng, S. Luo, Environ Pollut 237, 218 (2018)

10. X. Xie, J.L. Ross, J.K. Cowell, Y. Teng, Future Med Chem 7, 1395 (2015)

11. B.C. Das, L. Mccormick, P. Thapa, R. Karki, T. Evans, Future Med Chem 5, 2103 (2013)

12. J.P. Souza, J.F. Baretta, F. Santos, I.M.M. Paino, V. Zucolotto, Aquat Toxicol 186, 11 (2017)

13. L. Mu, Y. Gao, X. Hu, Environ Sci Technol 50, 8530 (2016)

14. Y. Chen, C. Ren, S. Ouyang, X. Hu, Q. Zhou, Environ Sci Technol 49, 10147 (2015)

15. C. Ren, X. Hu, X. Li, Q. Zhou, Biomaterials 93, 83 (2016)

16. A.L. Fernandes, J.P. Nascimento, A.P. Santos, C.A. Furtado, L.A. Romano, C.E. Da Rosa, J.M. Monserrat, J. Ventura-Lima, Chemosphere 210, 458 (2018)

17. M. Chen, J. Yin, Y. Liang, S. Yuan, F. Wang, M. Song, H. Wang, Aquat Toxicol 174, 54 (2016)

18. Y. Zhang, T. Meng, L. Shi, X. Guo, X. Si, R. Yang, X. Quan, Sci Total Environ 649, 163 (2019)

19. J. Lu, X. Zhu, S. Tian, X. Lv, Z. Chen, Y. Jiang, X. Liao, Z. Cai, B. Chen, Chemosphere 211, 390 (2018)

20. V.L. Castro, Z. Clemente, C. Jonsson, M. Silva, J.H. Vallim, A.M. Zigiotto De Medeiros, D.S.T. Martinez, Environ Toxicol Chem 37, 1998 (2018)

21. S. Zhu, F. Luo, W. Chen, B. Zhu, G. Wang, Sci Total Environ 595, 101 (2017)

22. J.P. Souza, F.P. Venturini, F. Santos, V. Zucolotto, Chemosphere 190, 218 (2018)

23. W. Zou, Q. Zhou, X. Zhang, L. Mu, X. Hu, Ecotoxicol Environ Saf 159, 221 (2018)

24. C.-J. Lu, X.-F. Jiang, M. Junaid, Y.-B. Ma, P.-P. Jia, H.-B. Wang, D.-S. Pei, Chemosphere 184, 795 (2017)

25. Z. Clemente, V.L.S.S. Castro, L.S. Franqui, C.A. Silva, D.S.T. Martinez, Environ Pollut 225, 118 (2017)

26. C.H. Deng, J.L. Gong, G.M. Zeng, P. Zhang, B. Song, X.G. Zhang, H.Y. Liu, S.Y. Huan, Chemosphere 184, 347 (2017)
27. Y. Tu, M. Lv, P. Xiu, T. Huynh, M. Zhang, M. Castelli, Z. Liu, Q. Huang, C. Fan, H. Fang, et al., Nature Nanotechnology 8, 594 (2013)

28. Q. Yu, B. Zhang, J. Li, T. Du, X. Yi, M. Li, W. Chen, P.J.J. Alvarez, Nanotoxicology 11, 1102 (2017)

29. M. Garacci, M. Barret, F. Mouchet, C. Sarrieu, P. Lonchambon, E. Flahaut, L. Gauthier, J. Silvestre, E. Pinelli, Carbon 113, 139 (2017)

30. J. Chen, S. Li, J. Luo, Y. Zhang, W. Ding, Journal of Nanoscience and Nanotechnology 17, 186 (2017)

31. X. Jia, M. Hofmann, V. Meunier, B.G. Sumpter, J. Delgado, J.M. Romo-Herrera, H. Son, Y.P. Hsieh, A. Reina, J. Kong, et al., Science 323, 1701 (2009)

32. P.F.M. Nogueira, D. Nakabayashi, V. Zucolotto, Aquat Toxicol 166, 29 (2015)

33. X. Lu, X. Feng, J.R. Werber, C. Chu, I. Zucker, J.H. Kim, C.O. Osuji, M. Elimelech, Proc Natl Acad Sci U S A 114, E9793 (2017)

34. S. Du, P. Zhang, R. Zhang, Q. Lu, L. Liu, X. Bao, H. Liu, Chemosphere 164, 499 (2016)

35. J.C. Espinosa, S. Navalon, A. Primo, M. Moral, J. Fernandez Sanz, M. Alvaro, H. Garcia, Chemistry-a European Journal 21, 11966 (2015)

36. J.C. Espinosa, S. Navalon, M. Alvaro, H. Garcia, Chemcatchem 8, 2642 (2016)

37. Y. Zhao, W.F. Chen, C.F. Yuan, Z.Y. Zhu, L.F. Yan, Chinese Journal of Chemical Physics 25, 335 (2012)

38. X. Liu, S. Sen, J. Liu, I. Kulaots, D. Geohegan, A. Kane, A.A. Puretzky, C.M. Rouleau, K.L. More, G.T.R. Palmore, et al., Small 7, 2775 (2011)

39. J. Li, G. Wang, H. Zhu, M. Zhang, X. Zheng, Z. Di, X. Liu, X. Wang, Sci Rep 4, (2014)

40. N.A. Zubir, C. Yacou, J. Motuzas, X. Zhang, X.S. Zhao, J.C.D. Da Costa, Chem Commun 51, 9291 (2015)

41. L. Lyu, G. Yu, L. Zhang, C. Hu, Y. Sun, Environ Sci Technol 52, 747 (2018) 